\title{
Peptide-Modified Zwitterionic Porous Hydrogels for Endothelial Cell and Vascular Engineering
}

\author{
Chih-Yeh Lin, Yi-Ren Wang, Che-Wei Lin, Shih-Wen Wang, Hsiu-Wen Chien, \\ Nai-Chen Cheng, Wei-Bor Tsai, and Jiashing Yu
}

\begin{abstract}
Hydrogels allow control of gel composition and mechanics, and permit incorporation of cells and a wide variety of molecules from nanoparticles to micromolecules. Peptide-linked hydrogels should tune the basic polymer into a more bioactive template to influence cellular activities. In this study, we first introduced the generation of 2D poly-(sulfobetaine methacrylate [SBMA]) hydrogel surfaces. By incorporating with functional peptide RGD and vascular endothelial growth factor-mimicking peptide KLTWQELYQLKYKG (QK) peptides, endothelial cells attached to the surface well and proliferated in a short-term culturing. However, the mechanical property, which plays a crucial role directing the cellular functions and supporting the structures, decreased when peptides graft onto hydrogels. Manipulating the mechanical property was thus necessary, and the most related factor was the monomer concentration. From our results, the higher amount of SBMA caused greater stiffness in hydrogels. Following the 2D surface studies, we fabricated 3D porous hydrogels for cell scaffolds by several methods. The salt/particle leaching method showed a more reliable way than gas-foaming method to fabricate homogeneous and open-interconnected pores within the hydrogel. Using the salt/particle leaching method, we can control the pore size before leaching. Morphology of endothelial cells within scaffolds was also investigated by scanning electron microscopy, and histological analysis was conducted in vitro and in vivo to test the biocompatibility of SB hydrogel and its potential as a therapeutic reagent for ischemic tissue repair in mice.
\end{abstract}

Key words: endothelial cell; porous hydrogels; salt/particle leaching; tissue engineering

\section{Introduction}

$\mathbf{T}$

HE FIELDS OF TISSUE ENGINEERING include any applications of the principles and methods to restore, maintain, or improve tissue function. With all kinds of applications, cells, scaffolds, and signaling molecules play the important role and have been regarded as the most crucial factors in the field by their close interaction with each other. ${ }^{1}$ Bovine aortic endothelial cell (BAEC), the cell type used in this study, is one kind of vascular endothelial cells. Endothelial cells line the entire circulatory system from heart to the smallest capillaries in humans. Therefore, the aim of our study was to investigate the endothelial cells interacting with suitable biomaterials and induce angiogenesis for tissue repairing issue. $^{2-4}$

The culturing environment is critical for cell fate as well as other activities. For instance, differentiation phenomenon such as chondrogenesis, osteogenesis, and angiogenesis can be induced by modulating a variety of culturing environment. ${ }^{3}$ In order to establish a biomimetic environment, phys- ical clues relating the mechanical strength and the geometry of scaffolds should also be considered in designing the ideal scaffolds for cell and tissue engineering.

Hydrogels, the hydrophilic networks of polymer chains, have long been of great interest to scientists for many years. More applications of hydrogels such as artificial dressings, contact lenses, drug delivery vehicle, and cell scaffolds in the tissue engineering field have been found based on all kinds of natural and synthetic materials. ${ }^{5,6}$ In addition to the general properties of hydrogels, they are commonly considered be low fouling and more highly hydrated. Zwitterionic compounds are electrically neutral ionic compounds that have partially positive and negative charges simultaneously. Poly(2-methacryloyloxyethyl phosphorylcholine; MPC; Scheme 1) and poly(sulfobetaine methacrylate; SBMA; Scheme 2) are two kinds of typical monomers for zwitterionic compounds. Relying on this electrical characteristic, zwitterionic compounds show prominent hydrophilic property for making hydrogels. Furthermore, zwitterionic compounds also demonstrate the high resistance of protein and cell adsorption

Department of Chemical Engineering, National Taiwan University, Taipei, Taiwan. 
<smiles>C=C(C)C(=O)OCCOP(=O)([O-])OCC[N+](C)(C)C</smiles>

Scheme 1. A schematic of 2-methacryloyloxyethyl phosphorylcholine.

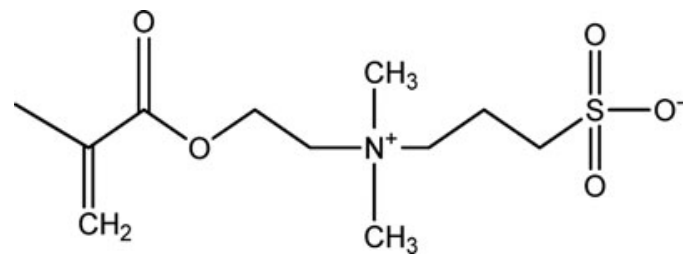

Scheme 2. A schematic of sulfobetaine methacrylate.

as a result of electrostatically induced hydration. The distinctive highly hydrated and nonfouling features are the most important properties of zwitterionic compounds. ${ }^{7-10}$

Three-dimensional porous hydrogels serve as a temporary support for cell accommodation and growth. They can be used to study 3D cell migration, controlled drug delivery, and as scaffolds for tissue engineering. A number of approaches have been used to generate porous scaffolds. The most common methods are solvent casting, particulate leaching, and gas foaming. Particulate leaching is a typical application that uses salt particles of a defined size range as porogens. Salt leaching method offers a number of advantages in generating porous materials. This method is simple and reproducible, allowing a wide range of pore sizes to be generated. ${ }^{11}$

To enhance the biochemical signal in cell and tissue engineering, a large number of impressive studies have featured in surface modification of biomaterials by conjugating the RGD peptide (Arg-Gly-Asp) with cell attachment activity. Different from the RGD peptide with the ubiquitous adhesive property, the $\mathrm{QK}$ sequence that was derived from vascular endothelial growth factor (VEGF) was also shown to have similar effect as the VEGF protein while being incorporated to support cell and proliferation., ${ }^{2,12-16}$

In this study, we first fabricated hydrogels for cell seeding in $2 \mathrm{D}$ surface and $3 \mathrm{D}$ porous structures by gas-foaming method and particulate-leaching method, and then we seeded endothelial cells to compare the cell morphology and adhe- sion property with and without grafting RGD and QK peptide sequences in order to enhance cell growth on the hydrogel surfaces.

\section{Materials and Methods}

\section{Chemicals and materials}

[2-(Methacryloyloxy)ethyl]dimethyl-(3-sulfopropyl)ammonium hydroxide (SBMA), ammonium persulfate (APS), $N, N, N^{\prime}, N^{\prime}-$ tetramethylethylenediamine (TEMED), poly(ethylene glycol) dimethacrylate (PEGDMA), trimethylolpropane trimethacrylate (TMPTMA), and phosphate-buffered saline (PBS) were purchased from Sigma-Aldrich. Ethylene glycol dimethacryl (EGDMA) was purchased from Alfa Aesar. Dulbecco's modified Eagle's medium (DMEM) was purchased from Thermo Scientific. Fetal bovine serum and penicillinstreptomycin-amphotericin B were purchased from Biological Industries. Peptides acryl-GYGRGDSP (RGD) and acryl-KLTWQELYQLKYKGI (QK) were purchased from Yao-Hong Biotechnology Inc. ${ }^{17}$ MTT assay reagents, thiazolyl blue tetrazolium bromide 3-[4,5-dimethylthiazol-2yl]-2,5-diphenyltetrazolium bromide (MTT), LDH-release assay reagents, sodium L-lactate, $\beta$-Nicotinamide adenine dinudeotide $\left(\mathrm{NAD}^{+}\right)$, diaphorase, albumin from bovine serum, sucrose, and iodonitrotetrazolium violet (TNT) were purchased from Sigma-Aldrich.

\section{Synthesis of poly-(SBMA) hydrogels}

By free radical polymerization, poly-(SBMA) hydrogel precursors including SBMA as monomer and methacrylate as crosslinker were dispersed in PBS buffer (pH 7.4) evenly with a solution phase. SBMA was at a concentration of 20 $50 \%(\mathrm{w} / \mathrm{v})$ and the crosslinker (PEGDMA, TMPTMA, or EGDMA) was $1 \%(\mathrm{w} / \mathrm{v})$. Then, the initiators (APS and TEMED) were added at the final concentration of $50 \mathrm{mM}$, respectively. The mixture was placed between two glass slides separated by $1-\mathrm{mm}$-thick polytetrafluoroethylene spacers and stood at $37^{\circ} \mathrm{C}$ for $30 \mathrm{~min}$ to polymerize (Supplementary Fig. S1). After polymerization, hydrogels were removed from the casts and soaked in PBS to swell. Then, the hydrated hydrogels were cut into 5-mm-diameter disks to proceed the cell tests. Solutions containing different amounts of peptide were polymerized using the same process mentioned and listed in Table $1 .^{18}$

\section{Generation of 3D scaffolds}

The procedure for 3D porous hydrogels was basically the same as 2D surfaces. After the hydrogel precursors were

Table 1. Composition of 2D Hydrogels Modified by Peptides

\begin{tabular}{lcccll}
\hline Group & SBMA & PEGDMA & APS/TEMED & PBS & \multicolumn{1}{c}{ Peptide } \\
\hline SB & $400 \mathrm{mg}$ & $133 \mu \mathrm{L}$ & $50 \mu \mathrm{L}(25 \mathrm{mM})$ & $800 \mu \mathrm{L}$ & X \\
RGD & $400 \mathrm{mg}$ & $133 \mu \mathrm{L}$ & $50 \mu \mathrm{L}(25 \mathrm{mM})$ & $800 \mu \mathrm{L}$ & RGD 2.0 mg \\
REDV & $400 \mathrm{mg}$ & $133 \mu \mathrm{L}$ & $50 \mu \mathrm{L}(25 \mathrm{mM})$ & $800 \mu \mathrm{L}$ & REDV 2.0 mg \\
QK & $400 \mathrm{mg}$ & $133 \mu \mathrm{L}$ & $50 \mu \mathrm{L}(25 \mathrm{mM})$ & $800 \mu \mathrm{L}$ & QK $1.0 \mathrm{mg}$ \\
RGD/QK & $400 \mathrm{mg}$ & $133 \mu \mathrm{L}$ & $50 \mu \mathrm{L}(25 \mathrm{mM})$ & $800 \mu \mathrm{L}$ & RGD $2.0 \mathrm{mg} \&$ QK $1.0 \mathrm{mg}$ \\
\hline
\end{tabular}

$\mathrm{X}$ : indicates no peptide.

APS, ammonium persulfate; PBS, phosphate-buffered saline; PEGDMA, poly(ethylene glycol) dimethacrylate; SBMA, sulfobetaine methacrylate; TEMED, N,N, $\mathrm{N}^{\prime}, \mathrm{N}^{\prime}$-tetramethylethylenediamine. 
Table 2. Gene Primer Sequence for RT-PCR and Real-Time RT-PCR

\begin{tabular}{|c|c|c|c|}
\hline Gene & Accession number & Primer sequence & Size $(b p)$ \\
\hline \multicolumn{4}{|c|}{ Conventional RT-PCR } \\
\hline GAPDH & NM_001034034.2 & F: CATTGACCTTCACTACATGGT & \multirow[t]{2}{*}{232} \\
\hline \multirow{3}{*}{ VEGF-A } & & R: ACCCTTCAAGTGAGCCCCAG & \\
\hline & NM_174216.1 & F: AGTTCATTTTCAAGCCGTCCT & \multirow[t]{2}{*}{149} \\
\hline & & R: CTCTCCTATGTGCTGGCTTTG & \\
\hline \multirow[t]{2}{*}{ KDR } & NM_001110000.1 & F: TGGCCCAACAATCAGAGCAG & \multirow[t]{2}{*}{154} \\
\hline & & R: GAACGGAGCCCATGTCAGTG & \\
\hline \multirow[t]{2}{*}{ FLT1 } & NM_001191132.2 & $\begin{array}{l}\text { F: GAAGGACGGGATGAGGATGC } \\
\text { R: ATGGCGTTGAGCGGAATGTA }\end{array}$ & \multirow[t]{2}{*}{186} \\
\hline & & Real-time RT-PCR & \\
\hline GAPDH & NM_001034034.2 & F: CAAGTTCAACGGCACAGTCA & 120 \\
\hline VEGF-A & NM_174216.1 & $\begin{array}{l}\text { F: TGACACAGAACTACCCATAGC } \\
\text { R: AGCCTCCTCTTCCTTCATGT }\end{array}$ & 106 \\
\hline KDR & NM_001110000.1 & $\begin{array}{l}\text { F: TTGCTCAAGATGCCACAGAA } \\
\text { R: CAGACATATCACATCAGGACAGA }\end{array}$ & 133 \\
\hline FLT1 & NM_001191132.2 & $\begin{array}{l}\text { F: CCATCTGAGGTCTCAACATAG } \\
\text { R: GGTCTAATAATGCCATCAATTCA }\end{array}$ & 141 \\
\hline
\end{tabular}

RT-PCR, reverse transcription-polymerase chain reaction.

mixed, the solutions were modulated to $\mathrm{pH} 3.7$ by $1 \mathrm{M} \mathrm{HCl}$ and kept at room temperature for $3.5 \mathrm{~min}$. Sodium bicarbonate $\left(\mathrm{NaHCO}_{3}\right.$; Sigma-Aldrich) powder $(5 \% \mathrm{w} / \mathrm{v})$ was added to the solution as a gas-foaming reagent, and we immediately vortexed the solution for several seconds so that gas bubbles can be generated and distributed evenly throughout the reaction solution. The solution was allowed to stand for more than $30 \mathrm{~min}$ to ensure complete polymerization (Supplementary Fig. S2). ${ }^{19-22}$

Together with the gas-foaming method, we also investigated the salt-leaching method. ${ }^{23}$ Excessive amounts of sodium chloride $(\mathrm{NaCl})$ powder (J.T. Baker) were dissolved in PBS to make saturated salt solution in advance. Then, the hydrogel precursor was mixed in saturated salt solution, which contained the same concentration as the one that was mentioned above. Sieved salt crystals ranging from 125 to $180 \mu \mathrm{m}, 180$ to $250 \mu \mathrm{m}$, and larger than $250 \mu \mathrm{m}$ were then added, respectively, to be porogens followed by adding initiators APS and TEMED. The solution was allowed to stand for more than $30 \mathrm{~min}$ to ensure complete polymerization.

\section{Swelling ratio measurement}

To measure the weight-to-swelling ratio, dried hydrogels were confined to wells to fabricate $5-\mathrm{mm}$-thick $1.1 \mathrm{~cm}^{2}$ round disks. After weighing by an electronic balance (ATY224; Shimadzu), samples were immersed in deionized water for

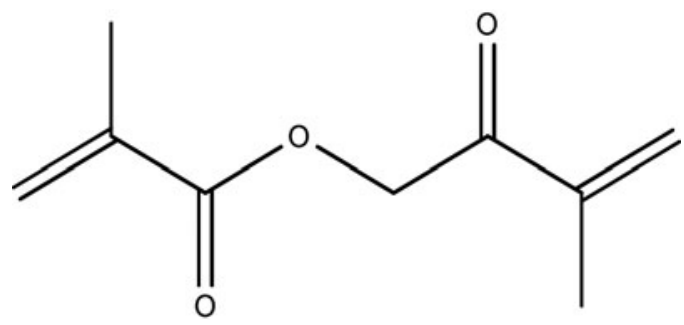

Scheme 3. A schematic of (ethylene glycol) dimethacrylate.
$48 \mathrm{~h}$ at room temperature, and then the swelling samples were weighed in the same way. The swelling ratio is calculated as follows:

$$
S=\left(W_{s}-W_{d}\right) / W_{d}
$$

where $W_{\mathrm{s}}$ and $W_{\mathrm{d}}$ are the weights of swollen and dried hydrogels, respectively. ${ }^{19,24,25}$

\section{Mechanical stiffness test}

The Young's modulus of poly-(SBMA) hydrogel was measured using an Elastic Modulus Load Cells LTS200GA (Kyowa) (Supplementary Fig. S3) and a Stepping Motor-Driven Stages SGSP(MS)20-85 (Sigma-Koki). Prior to the test, swelling hydrogels were cut into disks $(5 \mathrm{~mm}$ in diameter and $5 \mathrm{~mm}$ in thickness) and excessive water on the surface was removed with filter paper. Hydrogels were subjected to an unconfined uniaxial compression to break about $70 \%$ strain at a compression velocity $10 \mu \mathrm{m} / \mathrm{sec}$. The compressive stress-strain ratio was then determined and recorded with continuous stress to be analyzed. ${ }^{26}$

\section{Cell culture}

BAECs (courtesy of Academia Sinica, Taiwan) were cultured in DMEM-LG medium. Cell culture began with either high cell seeding density $\left(5 \times 10^{4}\right.$ cell $\left./ \mathrm{cm}^{2}\right)$ or low cell seeding density $\left(2 \times 10^{4} \mathrm{cell} / \mathrm{cm}^{2}\right)$ at $37^{\circ} \mathrm{C}$ and $5 \% \mathrm{CO}_{2}$ with changing medium every 2 days until confluence was reached.

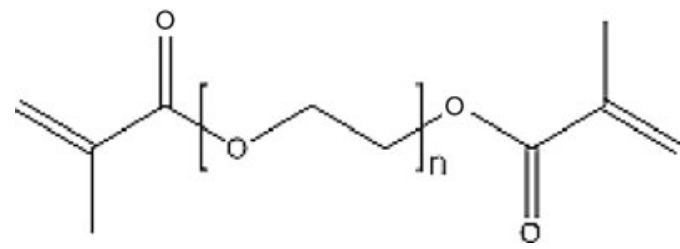

Scheme 4. A schematic of poly(ethylene glycol) dimethacrylate. 


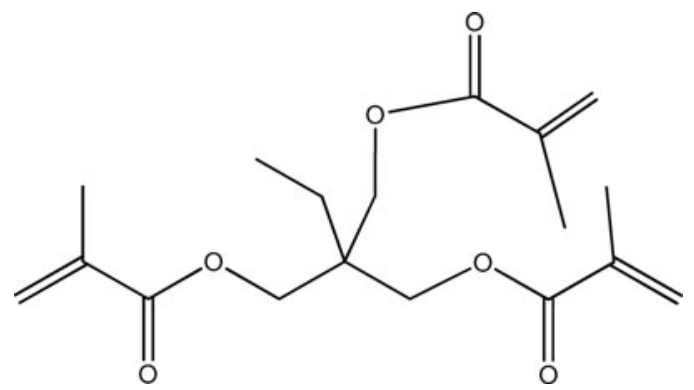

Scheme 5. A schematic of trimethylolpropane trimethacrylate.

PBS washing was performed during changing medium. Cells were treated with trypsin-EDTA (Biological) for 5 min at $37^{\circ} \mathrm{C}$ during the detaching procedure from the culture dish. To stop the enzyme reaction, culture medium was added to the dish. The number of suspended cells was counted using a hemocytometer; cells were stained with trypan blue to test the cell viability.

\section{MTT assay for cell adhesion ability}

After culture at $37^{\circ} \mathrm{C}$ and $5 \% \mathrm{CO}_{2}$ for 2 days, the original medium was removed. Then, MTT assay was carried out by adding $0.5 \mathrm{mg} / \mathrm{mL}$ MTT solution (tetrazolium salt 3-[4,5dimethylthiazol-2-yl]-2,5-diphenyltetrazolium bromide; SigmaAldrich) to each well and incubated for $3-4 \mathrm{~h}$ at $37^{\circ} \mathrm{C}$ to start the reaction. After incubation, MTT solution was aspirated and the same volume of dimethyl sulfoxide (DMSO) was added to each well. The insoluble purple product was dissolved completely in DMSO by vortexing on a shaker for 15$30 \mathrm{~min}$. Absorbance at $570 \mathrm{~nm}$ was measured using an ELISA spectrophotometer (Awareness Technology). The whole process was operated without light exposure. ${ }^{27,28}$

\section{LDH-release assay for cell proliferation}

BAECs were cultured at the seeding density $2 \times 10^{4}$ cell/ $\mathrm{cm}^{2}$ in $2 \mathrm{D}$ surfaces and $4 \times 10^{4}$ cell numbers in $3 \mathrm{D}$ porous scaffolds. To precisely quantify the cell activity, cell proliferation was determined by conducting LDH-release assay after 1 day, 7 days, and 14 days from cell seeding. Before conducting LDH-release assay, the LDH working solution was prepared by mixing the $\mathrm{LDH}$ stocking solution at the final concentration of $12 \mathrm{mg} / \mathrm{mL}$ sodium L-lactate, $1 \mathrm{mg}$ / $\mathrm{mL} \beta$-Nicotinamide adenine dinucleotide hydrate $\left(\mathrm{NAD}^{+}\right)$, $0.45 \mathrm{mg} / \mathrm{mL}$ diaphorase, $0.1 \mathrm{mg} / \mathrm{mL}$ bovine serum albu$\mathrm{min}, 4 \mathrm{mg} / \mathrm{mL}$ sucrose, and $0.67 \mathrm{mg} / \mathrm{mL}$ iodonitrotetrazolium violet. Cells were then rinsed twice with PBS carefully, followed by incubation of $0.2 \%$ Triton-X 100 to lyse the cells for $30 \mathrm{~min}$, and $50 \mu \mathrm{L}$ of the lysates was added into 96-well microplates. The enzymatic reaction was initiated after mixing $100 \mu \mathrm{L} \mathrm{LDH}$ working solution. Absorbance at $492 \mathrm{~nm}$ was measured using an ELISA spectrophotometer after the mixtures were incubated in $37^{\circ} \mathrm{C}$ for $15 \mathrm{~min}$.

\section{Scanning electronic microscopy observation}

Before SEM observation, hydrogel samples were immersed in $2.5 \%$ glutaraldehyde buffered with PBS at room temperature for at least $4 \mathrm{~h}$, and then samples were washed with PBS to rinse tissue three times. After the fixation steps, samples were dehydrated in graded ethanol solutions (Uni-onward), 30\%, 40\%, 50\%, 60\%, 70\%, 80\%, 90\%, and $100 \%$ (twice), for 15 min each. Critical-point drying was followed to exchange the ethanol residue by $\mathrm{CO}_{2}$ fluid for drying hydrogels (Hitachi; HCP-2).

Dried hydrogel samples were cut using a scalpel and sputter coated with palladium for scanning electron microscopy (SEM; Jeol; JSM-5310) imaging. SEM was used to investigate surface and interior morphology of the dried sections.

\section{Reverse transcription-polymerase chain reaction}

The RNA extraction procedure was operated according to the manufacturer's instructions of total RNA miniprep purification kit (GeneMark), and cDNA synthesis was performed using $1 \mu \mathrm{g}$ RNA by HiScript I First Strand cDNA Synthesis kit (Bionovas). The polymerase chain reaction (PCR) profile was $94^{\circ} \mathrm{C}$ for $5 \mathrm{~min} ; 35$ cycles of $94^{\circ} \mathrm{C}$ for $30 \mathrm{sec}, 56.5^{\circ} \mathrm{C}$ for $45 \mathrm{sec}$, and $72^{\circ} \mathrm{C}$ for $30 \mathrm{sec}$; and $72^{\circ} \mathrm{C}$ for $7 \mathrm{~min}$, and continuously at $4^{\circ} \mathrm{C}$. PCR (Bio-Rad) was performed using the primers listed in Table 2. Examination of the gene expression were carried out by electrophoresis using $1.5 \%$ agarose gel in $1 \times$ TAE buffer solution. After electrophoresis operation at $100 \mathrm{~V}$ for $60-75 \mathrm{~min}$, the DNA bands were visualized under UV light with the Safe-View stain (GeneMark) within gel. The DNA band intensity was analyzed with ImageJ and all gene expression was normalized to GAPDH.

\section{In vitro cell culture and in vivo examination of hydrogels}

In vitro cell studies were carried out by seeding BAECs at a concentration of $1 \times 10^{6} / \mathrm{mL}$ into $3 \mathrm{D}$ poly-(SBMA) hydrogels, which were 8-mm-diameter disks with and without RGD for 1 day $(N=2)$. All samples were treated with $2.5 \%$ glutaraldehyde solution for fixation for at least $4 \mathrm{~h}$. Then, the fixed samples were dehydrated and embedded for paraffin sections. We used hematoxylin and eosin $(\mathrm{H} \& \mathrm{E}$; Sigma-Aldrich) staining to evaluate the phenomenon related to neovascularization or angiogenesis.

Table 3. Gelation Results by Different Crosslinker and Monomer Concentration

\begin{tabular}{llllll}
\hline SBMA & Crosslinker & Gelation & SBMA & Crosslinker & Gelation \\
\hline $20 \mathrm{wt} \%$ & 0.5\% EGDMA & $\mathrm{X}$ & $20 \mathrm{wt} \%$ & TMPTMA & $\mathrm{X}$ \\
$20 \mathrm{wt} \%$ & 1\% EGDMA & O (sticky) & $35 \mathrm{wt} \%$ & TMPTMA & $\mathrm{X}$ \\
$35 \mathrm{wt} \%$ & EGDMA & $\mathrm{O}$ & $50 \mathrm{wt} \%$ & $2 \%$ TMPTMA & $\mathrm{X}$ \\
$50 \mathrm{wt} \%$ & EGDMA & $\mathrm{O}$ & $50 \mathrm{wt} \%$ & $5 \%$ TMPTMA & $\mathrm{X}$ \\
$20 \mathrm{wt} \%$ & PEGDMA & $\mathrm{O}$ & $50 \mathrm{wt} \%$ & $6.6 \%$ TMPTMA & O (sticky) \\
$50 \mathrm{wt} \%$ & PEGDMA & $\mathrm{O}$ & $50 \mathrm{wt} \%$ & $10 \%$ TMPTMA & O (sticky \& hard)
\end{tabular}

$\mathrm{X}$ : did not form gel; O: could form gel. 

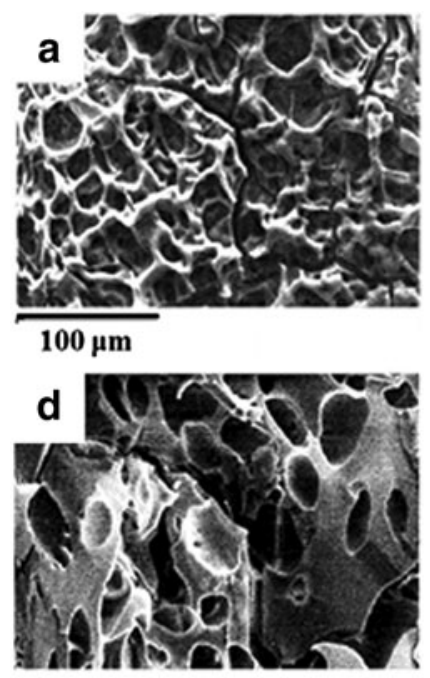

$100 \mu \mathrm{m}$

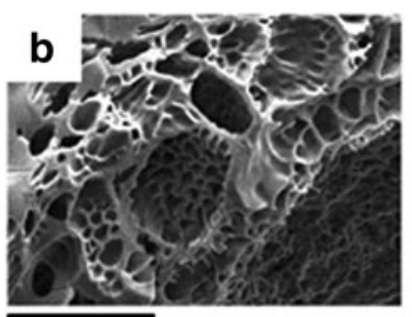

$100 \mu \mathrm{m}$

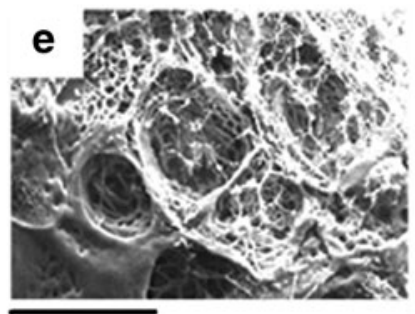

$100 \mu \mathrm{m}$

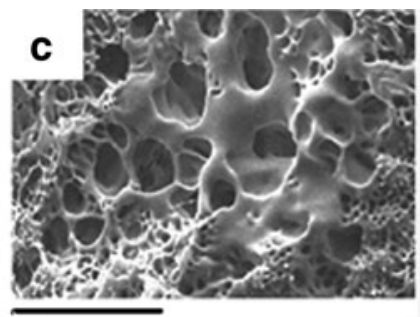

$100 \mu \mathrm{m}$

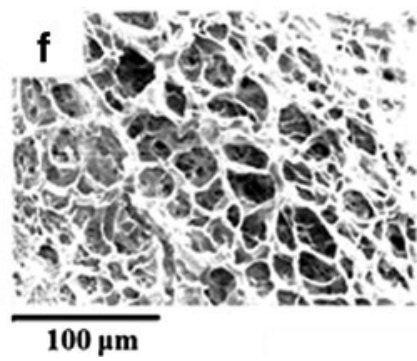

FIG. 1. SEM images of gas-foaming method. Conditions in first row are $20 \mathrm{wt} \%$ monomer and (a) $\mathrm{pH} 7.4$ without $\mathrm{NaHCO}_{3}$, (b) $\mathrm{pH} 7.4$ with $\mathrm{NaHCO}_{3}$, and (c) pH 3.7 with $\mathrm{NaHCO}_{3}$; conditions in second row are $50 \mathrm{wt} \%$ monomer and (d) $\mathrm{pH} 7.4$ without $\mathrm{NaHCO}_{3}$, (e) $\mathrm{pH} 7.4$ with $\mathrm{NaHCO}_{3}$, and (f) $\mathrm{pH} 3.7$ with $\mathrm{NaHCO}_{3}$. SEM, scanning electron microscopy.
In vivo animal study was carried out by injecting the hydrogel precursors (with or without cells) into subcutaneous part of 2-month-old female nude mice (Laboratory Animal Center, National Taiwan University, Taiwan; $N=3$ ) to test the gelation in vivo and observe the new vessel formation. We used the established ischemia models ${ }^{29,30}$ in the hind limb of mice for in vivo examination. In short, the mice that were underwent surgical ligature of the proximal part of the right femoral artery received the treatments immediately after the onset of ischemia; $150 \mu \mathrm{L}$ hydrogel precursors with a BAEC concentration of $1 \times 10^{6} / \mathrm{mL}$ was injected into the ischemic thigh muscle with a 26-gauge needle directly. The four groups were (1) SB gel only, (2) SB gel with cells, (3) RGD-modified SB gel without cells, and (4) RGD-modified SB gel with cells. The wounds were sutured and cleaned after implantation. The mice were observed daily and sacrificed after $24 \mathrm{~h}, 1$ week, and 2 weeks postimplanting ( $N=1$ each time point). The peripheral tissues were then taken out for histological evaluation.

\section{Statistical analysis}

All data are expressed as means \pm standard deviation. Different groups were compared using Student's $t$-test, and significant difference was assumed at $p \leq 0.05$. Statistical data were analyzed using Microsoft Excel (version 2010).

\section{Results}

\section{Synthesis of poly-(SBMA) hydrogels}

We used three chemicals, EGDMA (Scheme 3), PEGDMA (Scheme 4), and TMPTMA (Scheme 5), as three different types of crosslinker with concentration from $0.1 \%$ to $1 \%$ (w/ v). As summarized in Table 3, in all groups using PEGDMA as the crosslinker, no matter if the monomer concentration or the crosslinker concentration changed, they could still have excellent gelation property due to higher hydrophilicity and longer polymer chain structure. We thus chose PEGDMA at $1 \%$ as crosslinker in the following experiments.

\section{Generation of 3D scaffolds: gas-foaming method}

Porous hydrogels were fabricated by adding sodium bicarbonate $\left(\mathrm{NaHCO}_{3}\right)$ as gas-foaming agent. Figure 1 shows the SEM images of structures fabricated by gas-foaming technique. In Figure $1 \mathrm{a}$ and $\mathrm{d}$, the pSBMA hydrogels without any gas-foaming agents demonstrated few pores and the pores did not interconnect between each other. In Figure $1 \mathrm{~b}$ and e, structures can be much more porous and form more interconnecting pores adding $\mathrm{NaHCO}_{3}$.

To prevent the $\mathrm{CO}_{2}$ bubbles produced by dissociation of sodium bicarbonate in acidic environment, we changed the $\mathrm{pH}$ value using acidic solvent by adding $\mathrm{HCl}$ in advance. Figure 2
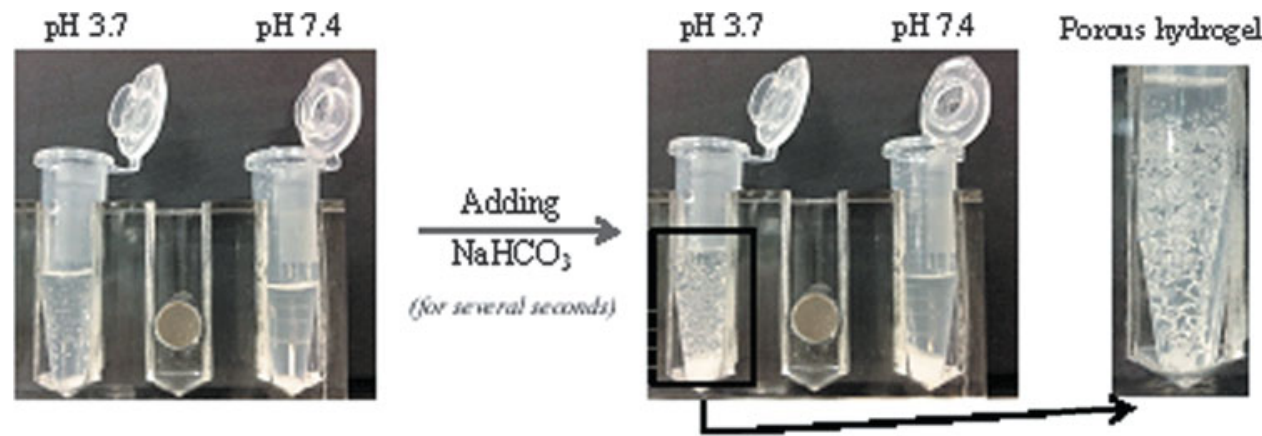

FIG. 2. Scheme of 3D porous hydrogels fabricated by gas-foaming method. 
FIG. 3. Scheme of 3D porous hydrogels fabricated by particle-leaching method.

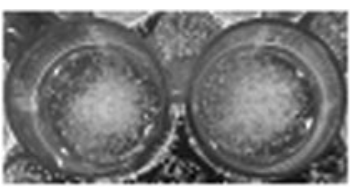

S alt crystals added in hydrogel sobutions

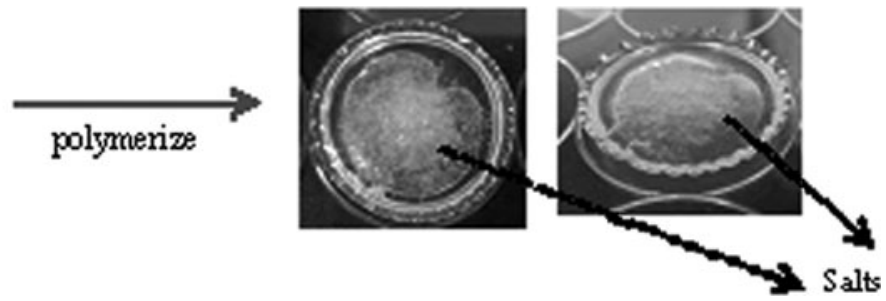

illustrates the $\mathrm{CO}_{2}$ foaming rates varied by modulating the $\mathrm{pH}$ value in 7.4 and 3.7. Acidic conditions increased the reaction rate and formed larger pores. From SEM images, many large bubbles were visually observed as in Figure $1 \mathrm{c}$ and $\mathrm{f}$.

\section{Generation of 3D scaffolds: salt-leaching method}

We believed that the size and amounts of porogens can largely affect the gelation process. Uncompleted polymerization might occur due to the large sizes and huge amounts of porogens, which hinder the crosslinking bonding sites and decrease the crosslinking densities. In our experiments, $\mathrm{NaCl}$ crystals larger than $250 \mu \mathrm{m}$ were used at $5 \mathrm{w} / \mathrm{v} \%$ concentration. Figure 3 illustrated the process of salt-leaching method by adding particles before polymerization and the SEM images are shown in Figure 4.

\section{Pore size analysis}

We analyzed the pore sizes and distribution by ImageJ to compare with those fabricated by gas-foaming method and salt-leaching method. Figure 5 shows bar charts of 100 random pore size distributions. Gas-foaming method produced a highly porous structure, but most of the pore diameter ranged only from about 75 to $100 \mu \mathrm{m}$ (from Fig. 5a) and few pores were larger than $1000 \mu \mathrm{m}$. In contrast, salt-leaching method can fabricate larger pore size and more uniform structure from about 400 to $500 \mu \mathrm{m}$ in diameter, making better cell scaffolds for cell tunneling through interconnected pores.

\section{Swelling ratio measurement}

Due to the highly hydrated property of poly-(SBMA) hydrogels, hydrogels swelled after soaking in PBS or DI water. The equilibrium swelling ratio was measured to understand the extent of hydrogel swelling. From Figure 6, we conclude that the ratios might change significantly according to different composition. Figure $6 \mathrm{a}$ indicates that the monomer dependence of the ratios of $20,30,40$, and $50 \mathrm{wt} \%$ in $2 \mathrm{D}$ hydrogels was $42 \pm 8 \%, 89 \pm 7 \%, 116 \pm 12 \%$, and $148 \pm 10 \%$, respectively, and the ratio of $20 \mathrm{wt} \%$ with RGD was $32 \pm 2 \%$. Additionally, Figure $6 \mathrm{~b}$ shows that the results of $20 \mathrm{wt} \% 3 \mathrm{D}$ hydrogels with and without RGD were $122 \pm 17 \%$ and $97 \pm 19 \%$, respectively.

\section{Mechanical stiffness test}

The compressive Young's modulus was measured to understand the physical property of poly-(SBMA) hydrogels for fabricating suitable biomaterials. Figure 7 showed the modulus of dense and porous hydrogels in different monomer concentrations. The stress-strain relationship can be separated into three regions: linear region for small deformations (region I), stiffening regions (region II), and linear region for large deformations (region III). Figure 8 shows the Young's modulus results of grafting RGD on $20 \mathrm{wt} \%$ poly(SBMA) hydrogel at stiffening region (region II). The values were $19.85 \pm 18 \% \mathrm{kPa}$ in the dense $\mathrm{SB}$ control group, $9.82 \pm 0.4 \% \mathrm{kPa}$ in the dense RGD group, $3.53 \pm 23 \% \mathrm{kPa}$ in the porous $\mathrm{SB}$ control group, and $1.27 \pm 14 \% \mathrm{kPa}$ in the porous
FIG. 4. SEM images of salt-leaching method: (a and b) $0 \%$ salt particles, (c and d) 5\% salt particles, and (e and f) $10 \%$ salt particles.
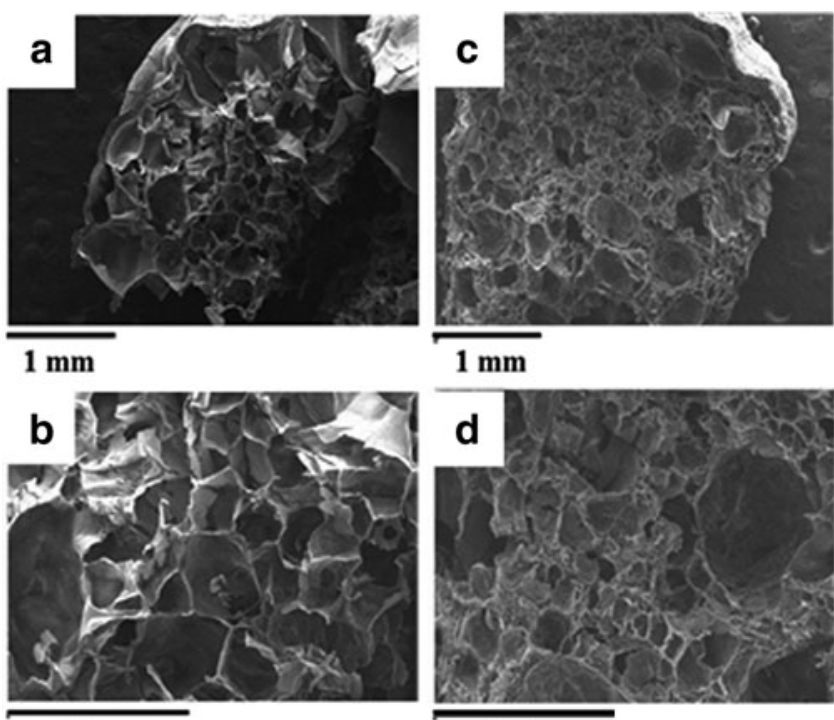

$600 \mu \mathrm{m}$

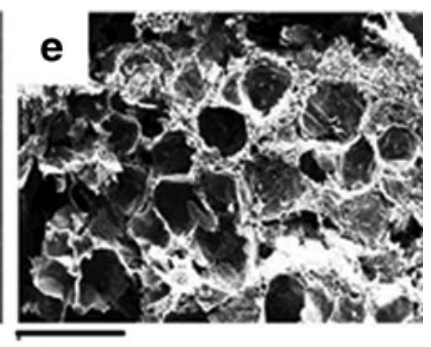

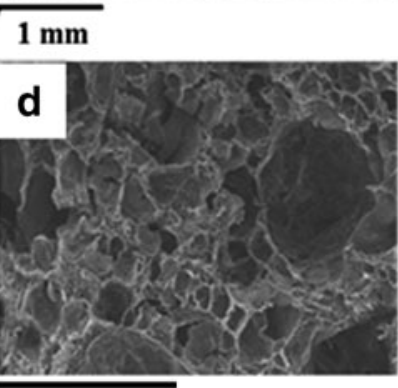

$600 \mu \mathrm{m}$

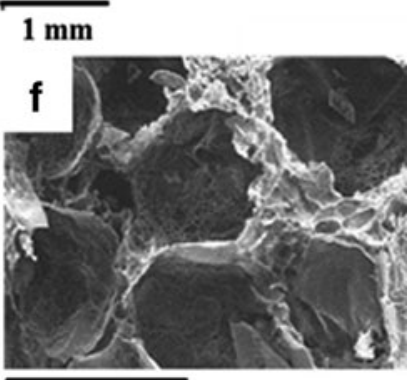

$600 \mu \mathrm{m}$ 

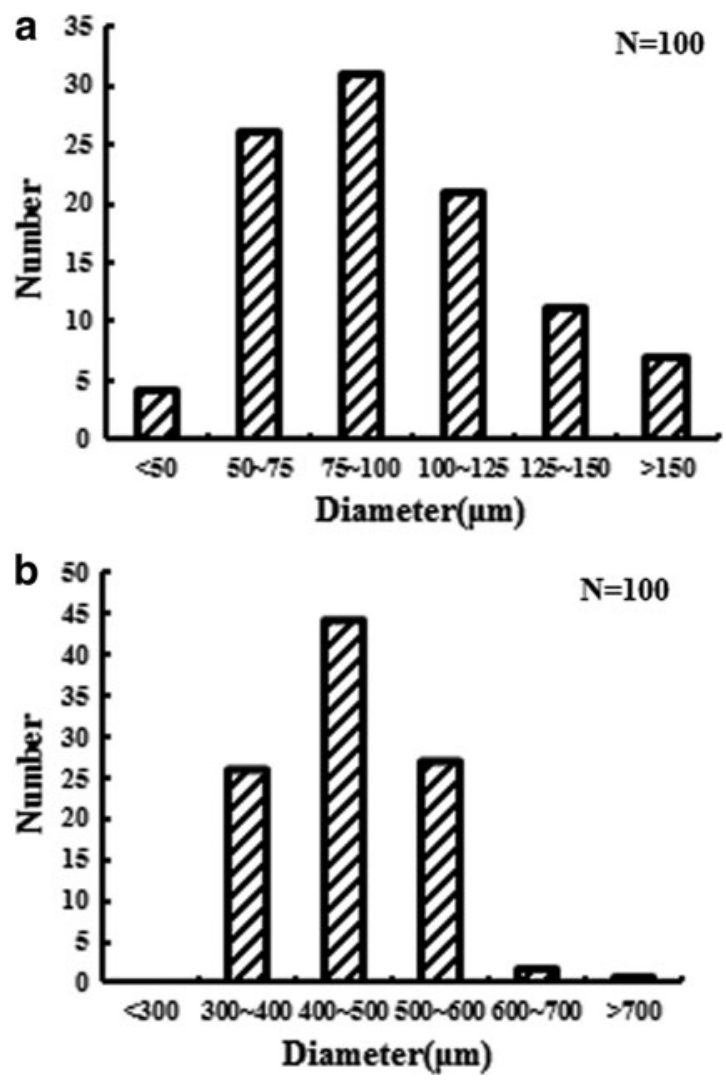

FIG. 5. Distribution of pore diameter of SB porous hydrogel by (a) gas-foaming method and (b) salt-leaching method.
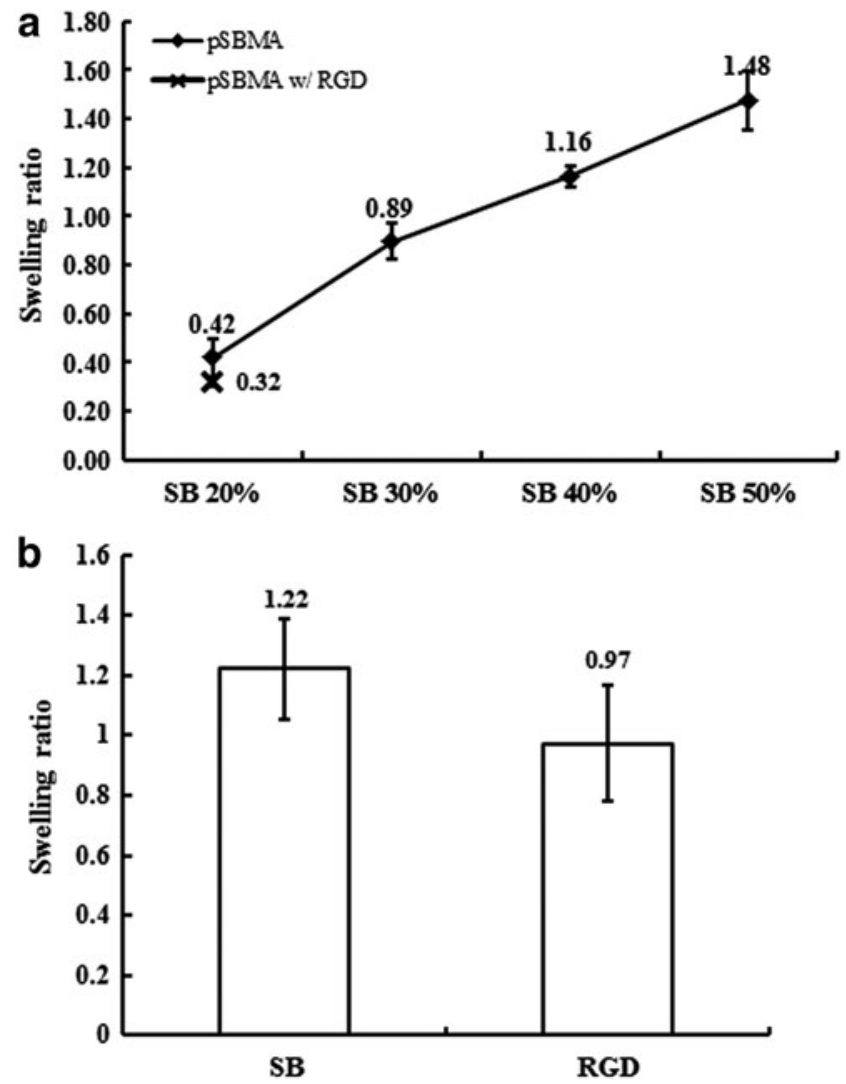

FIG. 6. Swelling ratio results. (a) $2 \mathrm{D}$ hydrogel with different SBMA concentration, and (b) 3D hydrogel with $20 \mathrm{wt} \%$ SBMA. SBMA, sulfobetaine methacrylate.
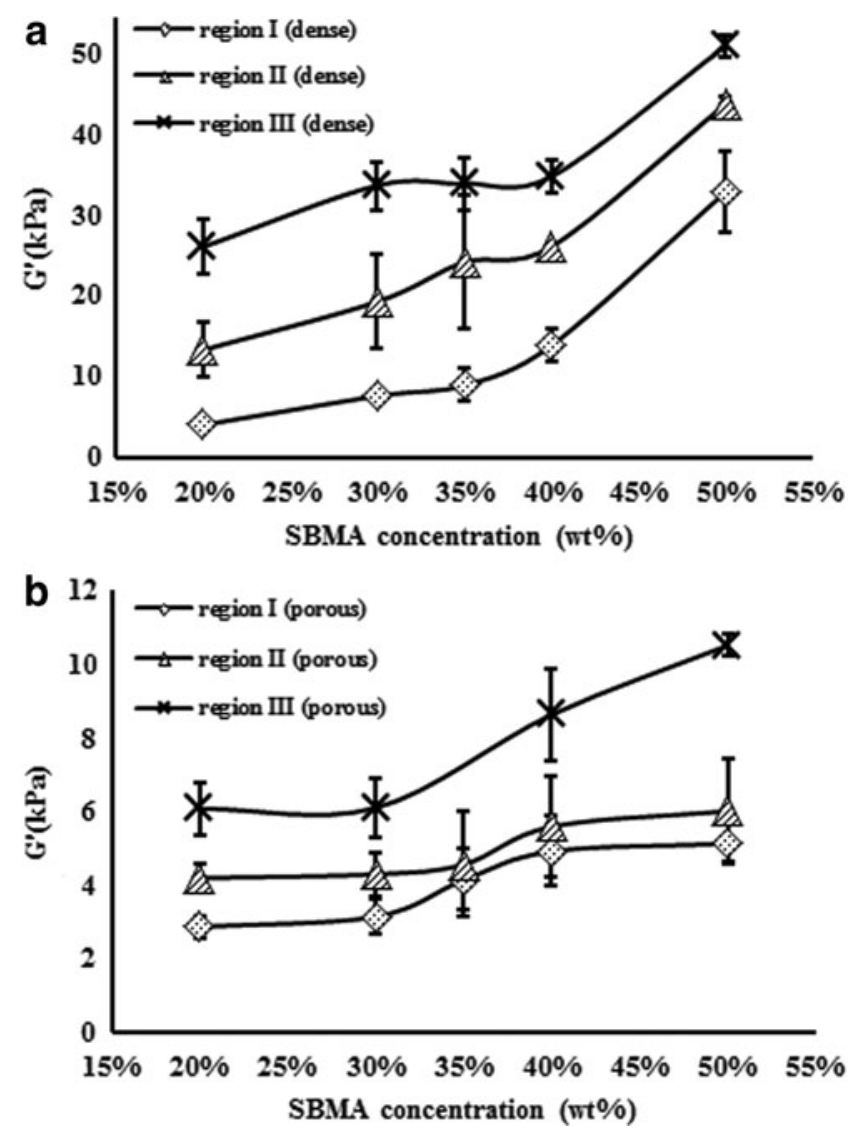

FIG. 7. Young's modulus of (a) dense hydrogels and (b) porous $3 \mathrm{D}$ hydrogels.
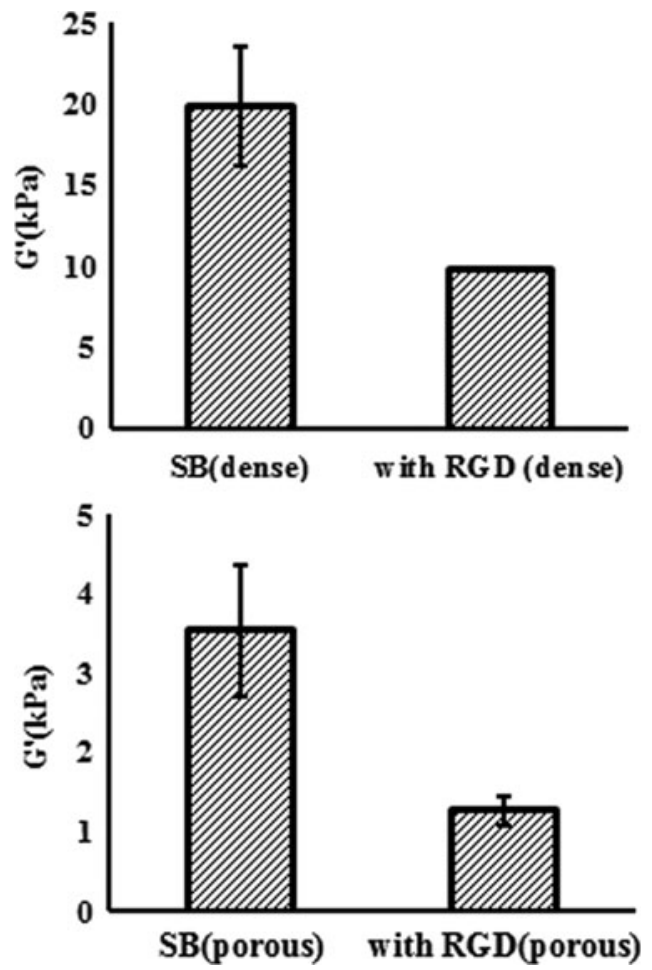

FIG. 8. Young's modulus results of hydrogels with and without RGD peptide. 


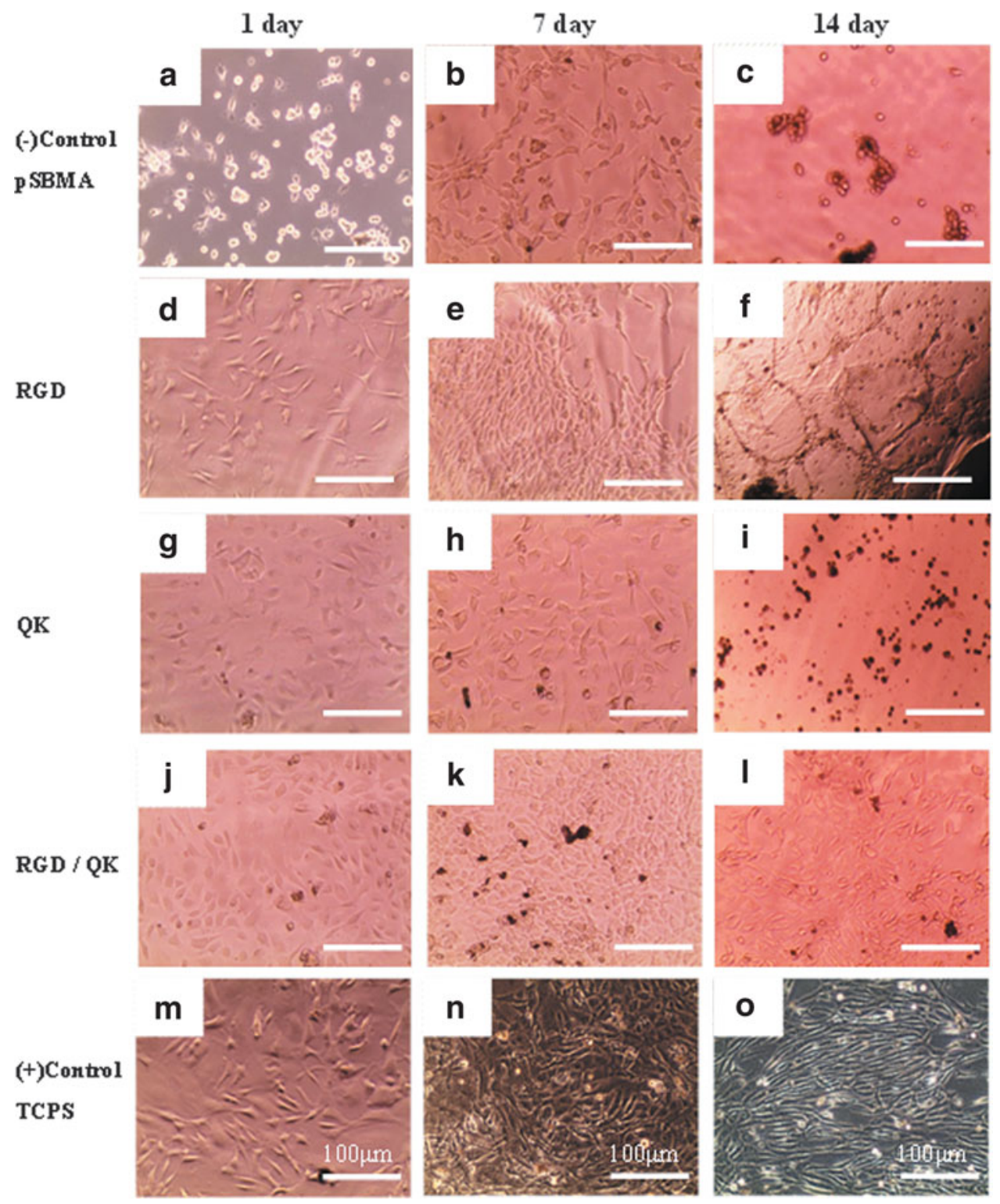

FIG. 9. Microscopic images of BAECs cultured on 2D hydrogel surfaces for 1,7 , and 14 days: (a-c) pSBMA hydrogel as negative control groups; (d-f) RGD-grafted pSBMA hydrogel; (g-i) QKgrafted pSBMA hydrogel; (j-l) RGD- and QK-grafted pSBMA hydrogel; (m-o) TCPS as positive control groups. BAECs, bovine aortic endothelial cells.

FIG. 10. SEM images of BAECs cultured on $3 \mathrm{D}$ porous hydrogels: pSBMA control group for (a) 1 day, (b) 7 days, and (c) 14 days; RGD group for (d) 1 day, (e) 7 days, and (f) 14 days.

RGD
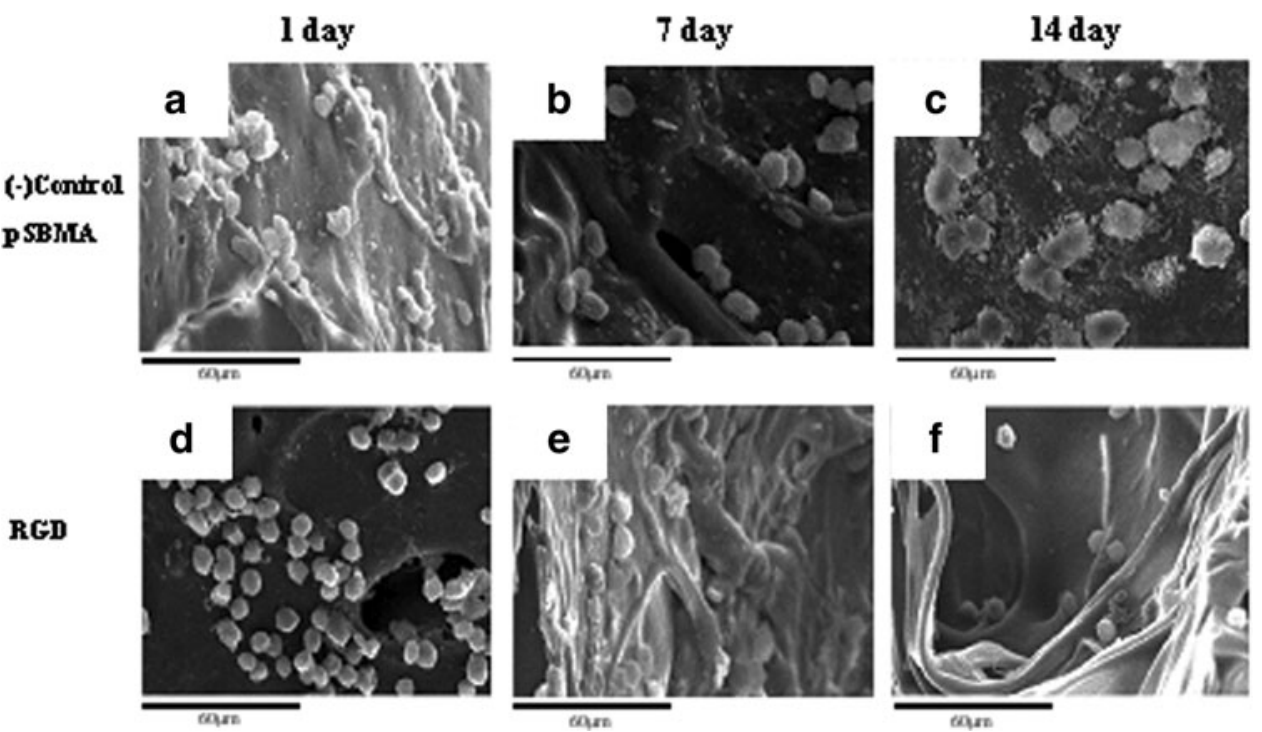


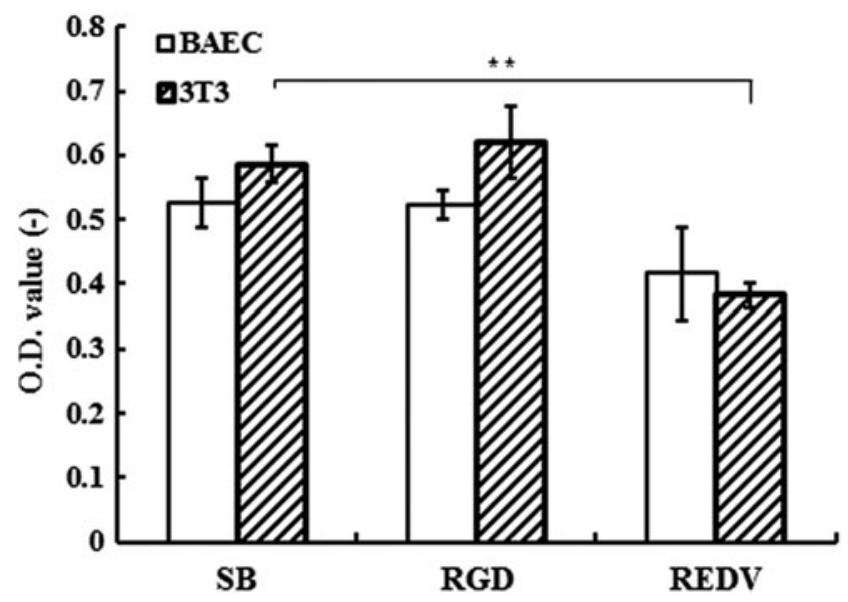

FIG. 11. Optical values by MTT assay: the relative cell viability results by testing cell initial adhesion for $48 \mathrm{~h}$. $* * p<0.01$.

RGD group. These results indicated about 30-50\% decrease in Young's modulus when RGD was grafted onto hydrogels.

\section{Cell morphology}

To investigate the effect of peptides on cell adhesion and proliferation properties, acryl-GYGRGDSP and acrylKLTWQELYQLKYKG(QK) sequences were grafted to fabricate $2 \mathrm{D}$ hydrogel surfaces. BAECs were cultured on the grafted surfaces of hydrogels for 1, 7, and 14 days. As shown in Figure 9, nonfouling properties can be observed obviously in negative control groups without peptide sequences; cells therefore adopted round shapes in Figure 9a, $\mathrm{b}$, and $\mathrm{c}$, while in the other groups with peptide sequences grafted, cells could adopt spindle shapes and show better cell adhesion properties. For example, in RGD-grafted surfaces and QK-grafted surfaces, cells attached properly and had a higher cell density for 1 day and 7 days (Fig. 9d, e, $\mathrm{g}$, and $\mathrm{h}$ ). Compared with RGD groups and QK groups for short-term periods ( 1 day; Fig. 9d and g), cells adhered and grew even better in QK-grafted surfaces than in RGD groups. We thus combined RGD and QK peptides together to improve cell adhesion property and proliferation simultaneously (Fig. 9j-1). These results indicated that BAECs' activities can be largely promoted through different peptides. However, long-term culturing for 14 days showed inadequate results for cells to grow on all groups of hydrogel surfaces even on tissue culture polystyrene (TCPS) surfaces.
SEM was used to observe the cell morphology of 3D cell culture in the hydrogel. The images were at 1,7 , and 14 days as shown in Figure 10. Cells retained round shape and did not adhere so well in either SB or RGD groups. Moreover, the difference can be seen between two groups after 14 days of seeding (Fig. 10c and f), where the cells aggregated into many clusters only in the SB group, but remained solely intact in the RGD group.

\section{MTT assay for cell adhesion ability}

In Figure 11, the result of MTT assay $(N=4)$ showed that there was no significant enhancement in groups grafting with RGD or REDV for culturing BAECs, which was in contradiction to our expectation. The reason was that grafting peptides on poly-(SBMA) hydrogels could decrease the Young's modulus for about $20 \%$ in our former results. The stiffness of hydrogels, which varied by adding different amounts of monomers and peptides, influenced cell adhesion; therefore, we can construct different environments for cells to display the cell adhesion property in different extents.

To examine the selectively endothelial cell adhesion improvement of the REDV peptide sequence, we cultured 3T3 with DMEM (high glucose) to compare with BAECs. Although from optical values there was no significant increase in RGD groups for two kinds of cells, the value of the REDV group for culturing 3T3 was significantly lower than that of the SB group. But we still cannot conclude the effect of REDV for selectively enhancing cell adhesion from the concentration of $1-4 \mathrm{mM}$, and so we still chose the RGD sequence to improve cell adhesion for further experiments.

\section{LDH-release assay for cell proliferation}

After seeding cells for 1-7 days, LDH-release assay was performed for all groups. Figure 12 a shows the cell density in 2D cell culture after 1,3 , and 7 days. RGD and RGD/ QK groups held relatively high cell densities compared with SB control groups, while in the QK group, cell amounts increased in short-term culturing after 1 day but decreased after 3 days due to nonfouling property. These trends were consistent with the results of cell adhesion property.

Three-dimensional cell culturing for 1-7 days was conducted in four groups and cells were quantified as shown in Figure 12b. Cell amounts in QK and RGD/QK groups increased significantly after 7 days' culturing, while those in SB and RGD groups did not. We deduced that not only
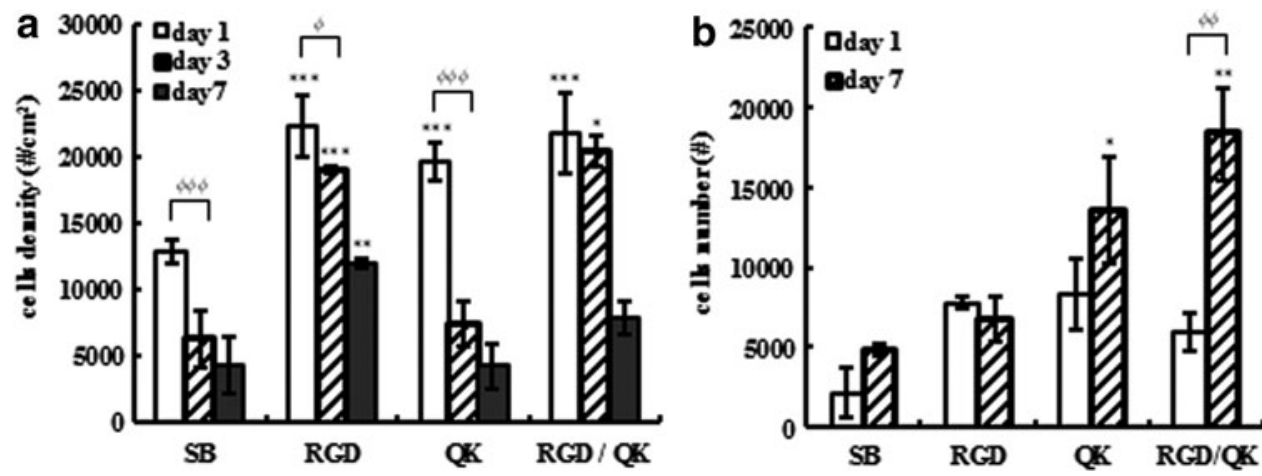

FIG. 12. Results of cell quantification by LDHrelease assay: (a) 2D cell culture and (b) 3D cell culture $(* p<0.05, * * p<0.01$, $* * * p<0.001$ compared to $\mathrm{SB} ; \phi_{p}<0.05, \phi \phi p<0.01$, $\phi \phi \phi p<0.001$ compared to day 1). 


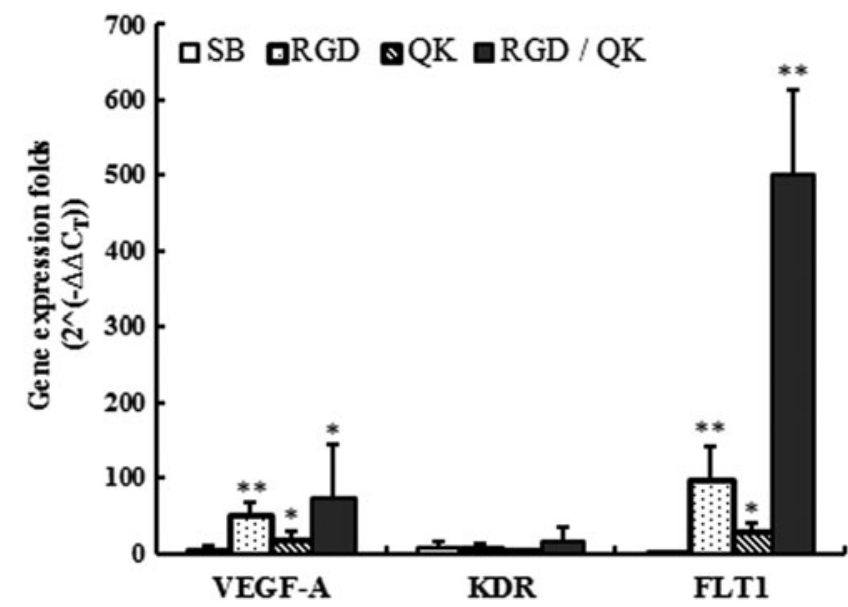

FIG. 13. Gene expression results by real-time reverse transcription-polymerase chain reaction for endothelial related genes $V E G F-A, K D R$, and FLT1. ${ }^{*} p<0.05$, ** $p<0.01$.

adhesion ability but also the structure of scaffolds affect cell proliferation in 3D cell culture prominently.

\section{Real-time RT-PCR}

To evaluate the angiogenesis potential of BAECs, we used real-time RT-PCR and chose three related genes, $V E G F-A$, $K D R$, and $F L T 1$, and tested gene expression for SB, RGD, $\mathrm{QK}$, and RGD/QK groups. After cell seeding on 2D hydrogel surfaces at the density of $1 \times 10^{5} / \mathrm{cm}^{2}$ for 2 days, cells were harvested for extracting the total RNA and conducting RTPCR. Cells on TCPS were selected as a control group to compare the $\Delta \Delta \mathrm{C}_{\mathrm{T}}$ value for relative quantification. In Figure 13, the results show that cells in RGD and RGD/QK groups expressed VEGF-A and FLT1 significantly higher than other groups. The results indicated the close relationship between cell adhesion and vascularization of endothelial cells. Hydrogels with $1 \mathrm{mM}$ QK concentration also had significant increase compared with control groups.

\section{Histological analysis}

We cultured BAECs into 3D porous hydrogels and used $\mathrm{H} \& \mathrm{E}$ staining for in vitro histological analysis. Figure 14 shows the microscopy images after cell seeding for $24 \mathrm{~h}$. Cells penetrated to the inner part both in the SB group and in the RGD group, but the amount of cells in the RGD group was larger than those in the SB group. The result was consistent with the observation of cell morphology as mentioned.

By injecting the hydrogel precursors into subcutaneous part of nude mice for in vivo study, blood vessel formation could be found by H\&E staining shown in Figure 15b (the endothelial cells and newly formed vessel were highlighted with circles). Then, we implanted SB hydrogels with or without RGD grafting in the ischemia models in the hind limb of mice. Figure 16a and $b$ indicates that in the SB group many foreign or immune cells aggregated in the skin part and muscle part for $24 \mathrm{~h}$, while in the RGD group, cells gathered in the bottom of skin but did not cause any immune effect in the upper skin and muscle part. After 2 weeks, the RGD groups could be observed with many tubelike spots, which were most likely newly formed vessels (Fig. 17a, skin part, and $b$, muscle part). This phenomenon can be explained when more cells can live and repair tissues in the RGD group.

\section{Discussion}

When we compared the three types of crosslinkers, EGDMA showed weaker crosslinking ability than the others. We assumed that the shorter chemical structure of EGDMA
FIG. 14. In vitro $\mathrm{H} \& \mathrm{E}$ staining of (a) pure SB hydrogel, (b) SB hydrogel with cells, (c) RGD-modified hydrogel without cells, and (d) RGD-modified hydrogel with cells. H\&E, hematoxylin and eosin.
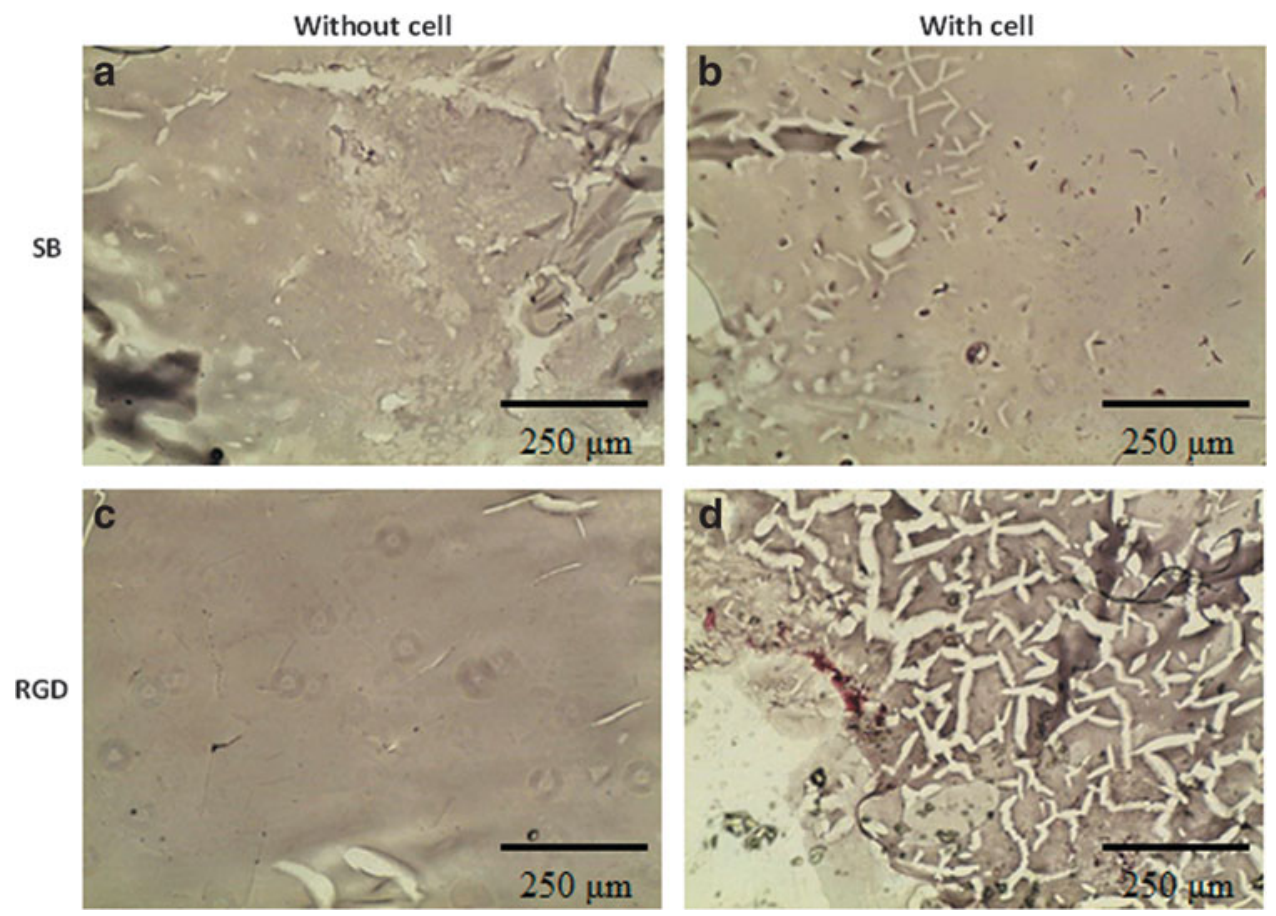


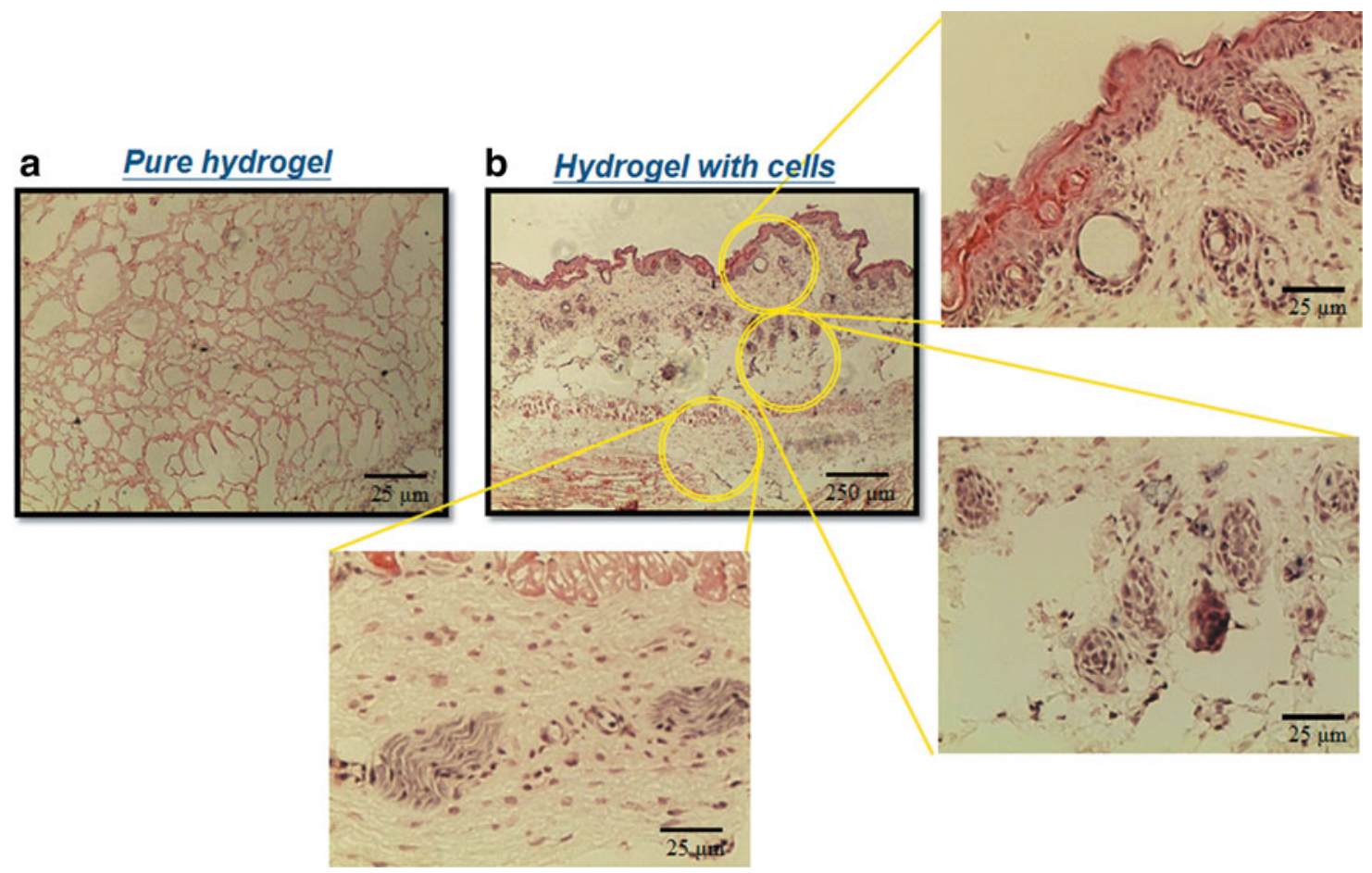

FIG. 15. Histological observation of subcutaneous injection for 3 weeks by H\&E staining: (a) pure hydrogel; (b) hydrogel with cells.

may lead to the phenomenon that the monomers could not bind together tightly. TMPTMA, which has more branched carbon chains, has relatively higher hydrophobicity. Therefore, hydrogel precursors could hardly mix uniformly with TMPTMA, and they could not be gelled successfully with some mild conditions. Only the relatively higher concentrations (50 wt \% monomer concentration, 6.6-10\% TMPTMA) could form hydrogels (Table 3 ).

In the process of the generation of 3D porous hydrogels, we found that producing $3 \mathrm{D}$ porous hydrogels by gas-
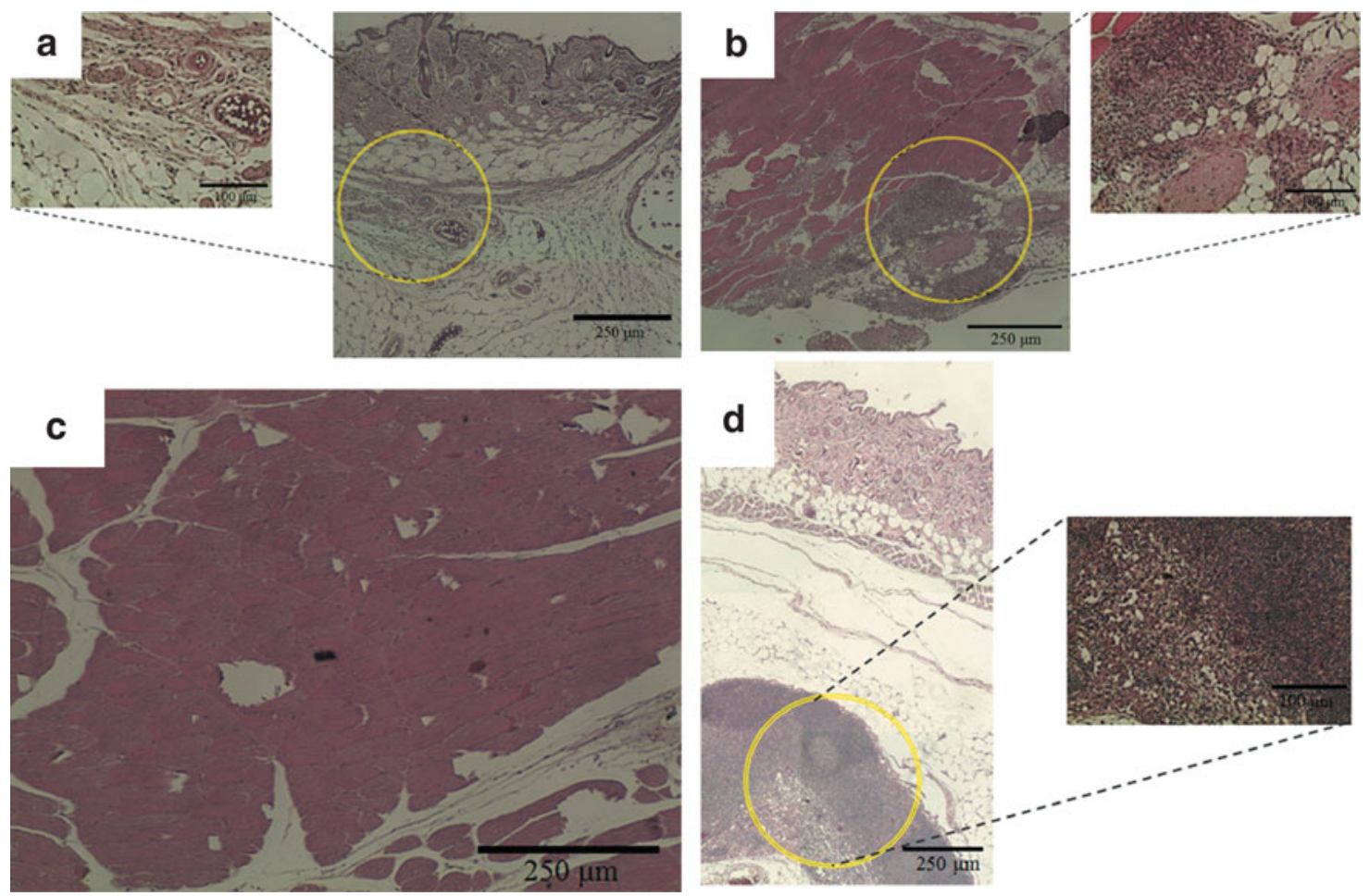

FIG. 16. In vivo histological observation from H\&E staining for $24 \mathrm{~h}$ : (a) skin, SB hydrogel with cells; (b) muscle, SB hydrogel with cells; (c) skin, RGD-modified hydrogel with cells; (d) muscle, RGD-modified hydrogel with cells. 
a
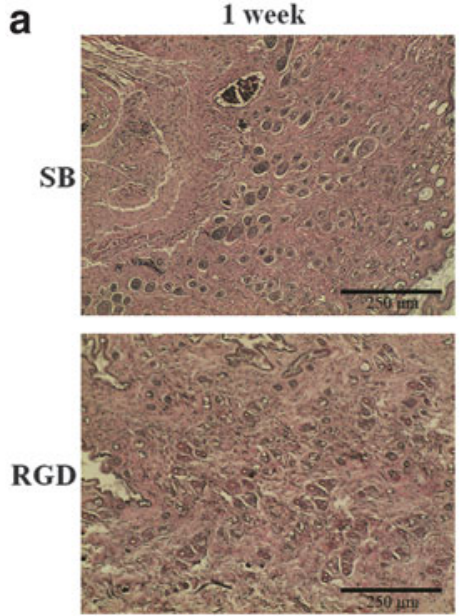

2 weeks
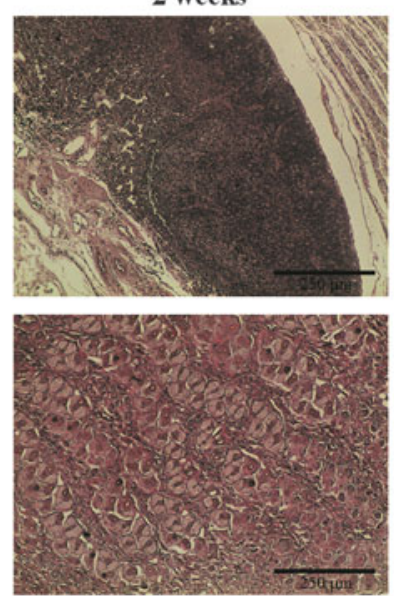

b
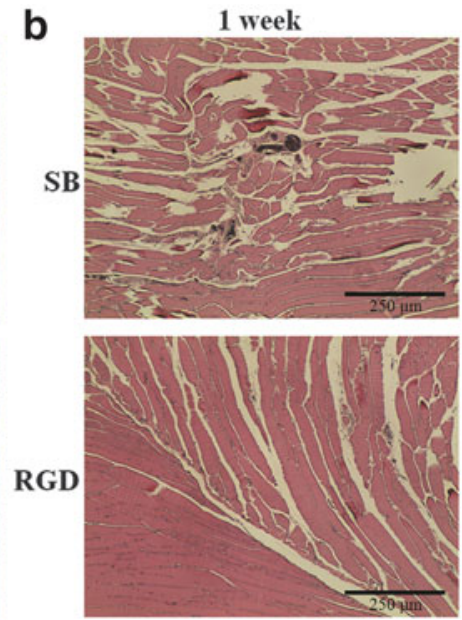
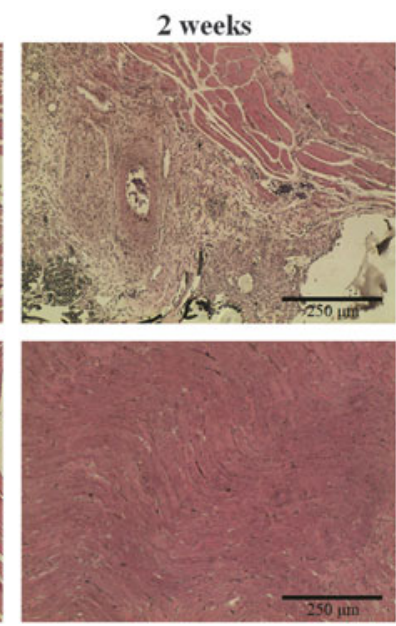

FIG. 17. In vivo histological observation from H\&E staining for 1-2 weeks: (a) skin part for SB and RGD groups; (b) muscle part for SB and RGD groups.

foaming method cannot make a homogeneous porous structure as cell scaffolds (Fig. 1). However, gas-foaming method is still a fashionable way of making super-porous structures in some other research. The consequences in our experiment may be caused by mixing high concentration of PEGDMA as a crosslinker in SBMA solution. The two-component mixture could influence the gas bubble to form within the solutions differing from the PEG-only hydrogels. Another possible rationale could be the $\mathrm{pH}$ value; the high acidity of hydrogel precursor may cause higher gas-foaming rate and form larger pores. ${ }^{20,21,31}$

In 2D endothelial cell culturing (Fig. 9), we examined the effects of peptides in cell adhesion and proliferation by two well-developed colorimetric techniques, MTT assay and LDH-release assay (Figs. 11 and 12). Yang et al. reported that different RGD concentrations can lead to cell growth and osteogenesis in PEG hydrogel platform. ${ }^{32,33}$ Our results showed that RGD concentration at $2 \mathrm{mM}$ or higher can significantly enhance cell attachment in morphology, and QK concentration at $1 \mathrm{mM}$ or higher provided a similar effect like VEGF to promote cell proliferation after seeding for 1-2 days. We believed that the dose dependence of peptides was crucial for modifying the surface of nonfouling hydrogels.

Besides, in the RGD/QK group, cells can proliferate faster in short-term and hold relatively higher amounts than other groups for 7 days by promoting cell proliferation and cell adhesion simultaneously (Fig. 12). However, the results of MTT assay showed a relative low value by modifying the REDV ligand (Fig. 11). It was because the decrease in mechanical property may change the roughness of hydrogel surfaces to decrease the cell adhesion property. ${ }^{34-36}$ Moreover, the 3D culturing was also influenced by geometry and stiffness (Fig. 10).

By testing the angiogenesis, two endothelial-related genes, $V E G F-A$ and $F L T 1$, expressed higher in groups with RGD and peptides from PCR results (Fig. 13), but the KDR gene did not show significant difference while the PCR process was based on few amounts of RNA extraction in this nonfouling platform. Therefore, we can observe the significance only in VEGF-A and FLT1 genes. The histological results also showed few newly formed vessels obviously (Figs. 14-16). However, future in vivo experiments with significant animal numbers with serial histological analysis and immunostaining of proliferation such as Ki-67 maker and CD31 marker for endothelial cells will be necessary to justify the potential of using the RGD/QK peptide-grafted SB hydrogels as an inductive angiogenic platform.

\section{Conclusions}

Zwitterionic hydrogels hold a substantial promise for creating functional engineered tissues with their highly hydrated and nonfouling properties. Some common methods, such as particulate leaching and gas foaming, have demonstrated the ability to create porous hydrogels. With the techniques presented here, the salt-leaching methods showed a better way to make homogeneous and open-interconnected porous structures. Cell morphology on 2D SBMA surface modified by RGD and QK had obvious improvements in adhesion property and proliferation compared to SBMA control surface. However, some physical properties between $3 \mathrm{D}$ porous scaffolds and 2D surfaces are very different. With the reducing Young's modulus and 3D geometry, cells in the 3D structure with RGD did not aggregate, but the improvements in cell adhesion were restricted using just $2 \mathrm{mM}$ RGD concentration as $2 \mathrm{D}$ cell culture experiments. Furthermore, to examine cell functions we conducted RT-PCR with endothelial-related genes, and results showed that groups with RGD and QK peptides expressed higher in VEGF-A and FLT1 (or named VEGF receptor 2) due to better cell adhesion and proliferation ability.

The results of our study indicate the possibility of using this platform of zwitterionic hydrogels to culture cells and promote many cell functions. The angiogenesis potential can be observed in the RT-PCR results when modifying specific peptides in $2 \mathrm{D}$ cell culturing. In addition, the physical properties and geometry in 3D scaffolds could influence the cell expression in morphology prominently. Thus, the constitution of SBMA, peptides, and solvent could be changed while producing a more suitable 3D cell scaffold. 
Last but not least, the in vivo study shows the potential of using this peptide-modified hydrogel as the therapeutic agent of a scaffold material and cell delivery carrier. Future studies including more time points and increased animal numbers will be necessary to prove the effect of injecting or implanting hydrogels for inducing vascularization or angiogenesis. Other cell types such as stem cells may also be investigated to expand the scope of using the zwitterionic porous hydrogels for regenerative and tissue engineering.

\section{Acknowledgment}

The authors gratefully acknowledge the financial support from National Science Council, Taiwan (NSC 102-2221-E002-039 and NSC 103-2221-E-002-210).

\section{Author Disclosure Statement}

No competing financial interests exist.

\section{References}

1. Curtis A, Riehle M. Tissue engineering: the biophysical background. Phys Med Biol. 2001;46:R47-R65.

2. Koepsel JT, Nguyen EH, Murphy WL. Differential effects of a soluble or immobilized VEGFR-binding peptide. Integr Biol (Camb). 2012;4:914-924.

3. Peppas NA, Lanza RP, Langer R, Chick WL. Principles of tissue engineering. Nature. 1997;389:453.

4. Elliott NT, Yuan F. A review of three-dimensional in vitro tissue models for drug discovery and transport studies. J Pharm Sci. 2011;100:59-74.

5. Hoffman AS. Hydrogels for biomedical applications. Ann N Y Acad Sci. 2001;944:62-73.

6. Pal K, Banthia AK, Majumdar DK. Polymeric hydrogels: characterization and biomedical applications. Des Monom Polym. 2009; 12:197-220.

7. Carr LR, Zhou YB, Krause JE, et al. Uniform zwitterionic polymer hydrogels with a nonfouling and functionalizable crosslinker using photopolymerization. Biomaterials. 2011;32: 6893-6899.

8. Zhang Z, Chen S, Chang Y, Jiang S. Surface grafted sulfobetaine polymers via atom transfer radical polymerization as superlow fouling coatings. J Phys Chem B. 2006;110: 10799-10804.

9. Hennink WE, van Nostrum CF. Novel crosslinking methods to design hydrogels. Adv Drug Deliv Rev. 2012;64:223-236.

10. Lowe AB, Billingham NC, Armes SP. Synthesis of polybetaines with narrow molecular mass distribution and controlled architecture. Chem Commun. 1996:17;2103.

11. Annabi N, Nichol JW, Zhong X, et al. Controlling the porosity and microarchitecture of hydrogels for tissue engineering. Tissue Eng Part B Rev. 2010;16:371-383.

12. Chan LY, Gunasekera S, Henriques ST, et al. Engineering pro-angiogenic peptides using stable, disulfide-rich cyclic scaffolds. Blood. 2011;118:6709-6717.

13. Santulli $\mathrm{G}$, Ciccarelli $\mathrm{M}$, Palumbo $\mathrm{G}$, et al. In vivo properties of the proangiogenic peptide QK. J Transl Med. 2009;7:41.

14. D'Andrea LD, Iaccarino G, Fattorusso R, et al. Targeting angiogenesis: structural characterization and biological properties of a de novo engineered VEGF mimicking peptide. Proc Natl Acad Sci USA. 2005;102:14215-14220.

15. Massia SP, Hubbell JA. Vascular endothelial-cell adhesion and spreading promoted by the peptide Redv of the iiics re- gion of plasma fibronectin is mediated by integrin alpha-4beta-1. J Biol Chem. 1992;267:14019-14026.

16. Hubbell JA, Massia SP, Desai NP, Drumheller PD. Endothelial cell-selective materials for tissue engineering in the vascular graft via a new receptor. Bio-Technology. 1991;9: 568-572.

17. Chien HW, Tsai CC, Tsai WB, et al. Surface conjugation of zwitterionic polymers to inhibit cell adhesion and protein adsorption. Colloids Surf B Biointerf. 2013;107: 152-159.

18. Chien HW, Tsai WB, Jiang S. Direct cell encapsulation in biodegradable and functionalizable carboxybetaine hydrogels. Biomaterials. 2012;33:5706-5712.

19. Huh KM, Baek N, Park K. Enhanced swelling rate of poly(ethylene glycol)-grafted superporous hydrogels. J Bioactive Compat Polym. 2005;20:231-243.

20. Keskar V, Marion NW, Mao JJ, Gemeinhart RA. In vitro evaluation of macroporous hydrogels to facilitate stem cell infiltration, growth, and mineralization. Tissue Eng Part A. 2009;15:1695-1707.

21. Park Y, Liang J, Yang Z, Yang VC. Controlled release of clot-dissolving tissue-type plasminogen activator from a poly(L-glutamic acid) semi-interpenetrating polymer network hydrogel. J Control Release. 2001;75:37-44.

22. Gupta NV, Shivakumar HG. Preparation and characterization of superporous hydrogels as gastroretentive drug delivery system for rosiglitazone maleate. Daru. 2010;18: 200-210.

23. Chiu YC, Larson JC, Isom A Jr., Brey EM. Generation of porous poly(ethylene glycol) hydrogels by salt leaching. Tissue Eng Part C Methods. 2010;16:905-912.

24. Ghanbarzadeh S, Arami S, Pourmoazzen Z, et al. Plasma stable, $\mathrm{pH}$-sensitive fusogenic polymer-modified liposomes: a promising carrier for mitoxantrone. J Biomater Appl. 2013; 29:81-92.

25. Kim D, Park K. Swelling and mechanical properties of superporous hydrogels of poly (acrylamide-co-acrylic acid)/ polyethylenimine interpenetrating polymer networks. Polymer. 2004;45:189-196.

26. Waters SL, Alastruey J, Beard DA, et al. Theoretical models for coronary vascular biomechanics: progress \& challenges. Prog Biophys Mol Biol 2011;104:49-76.

27. Gerlier D, Thomasset N. Use of Mtt colorimetric assay to measure cell activation. J Immunol Methods. 1986;94:57-63.

28. Mosmann T. Rapid colorimetric assay for cellular growth and survival: application to proliferation and cytotoxicity assays. J Immunol Methods. 1983;65:55-63.

29. Huang NF, Niiyama H, De A, et al. Embryonic stem cellderived endothelial cells for treatment of hindlimb ischemia. J Vis Exp. 2009; pii:1034.

30. Niiyama H, Huang NF, Rollins MD, Cooke JP. Murine model of hindlimb ischemia. J Vis Exp. 2009;23:1035.

31. Vishal Gupta N, Shivakumar HG. Preparation and characterization of superporous hydrogels as gastroretentive drug delivery system for rosiglitazone maleate. Daru. 2010;18: 200-210.

32. Yang F, Williams CG, Wang DA, et al. The effect of incorporating RGD adhesive peptide in polyethylene glycol diacrylate hydrogel on osteogenesis of bone marrow stromal cells. Biomaterials. 2005;26:5991-5998.

33. Roivainen M, Hyypia T, Piirainen L, et al. RGD-dependent entry of coxsackievirus A9 into host cells and its bypass after cleavage of VP1 protein by intestinal proteases. J Virol. 1991;65:4735-4740. 
34. Takakuwa O. [Influence of fluid shear stress on cultured vascular endothelial cells]. Hokkaido Igaku Zasshi. 1990;65: $178-188$.

35. Liu Y, Geever LM, Kennedy JE, et al. Thermal behavior and mechanical properties of physically crosslinked PVA/Gelatin hydrogels. J Mech Behav Biomed Mater. 2010;3:203-209.

36. Satcher R, Dewey CF Jr., Hartwig JH. Mechanical remodeling of the endothelial surface and actin cytoskeleton induced by fluid flow. Microcirculation. 1997;4:439-453.

Address correspondence to:

Jiashing $Y u, P h D$

Department of Chemical Engineering

National Taiwan University

No. 1, Sec. 4, Roosevelt Road

Taipei 10617

Taiwan

E-mail: jiayu@ntu.edu.tw

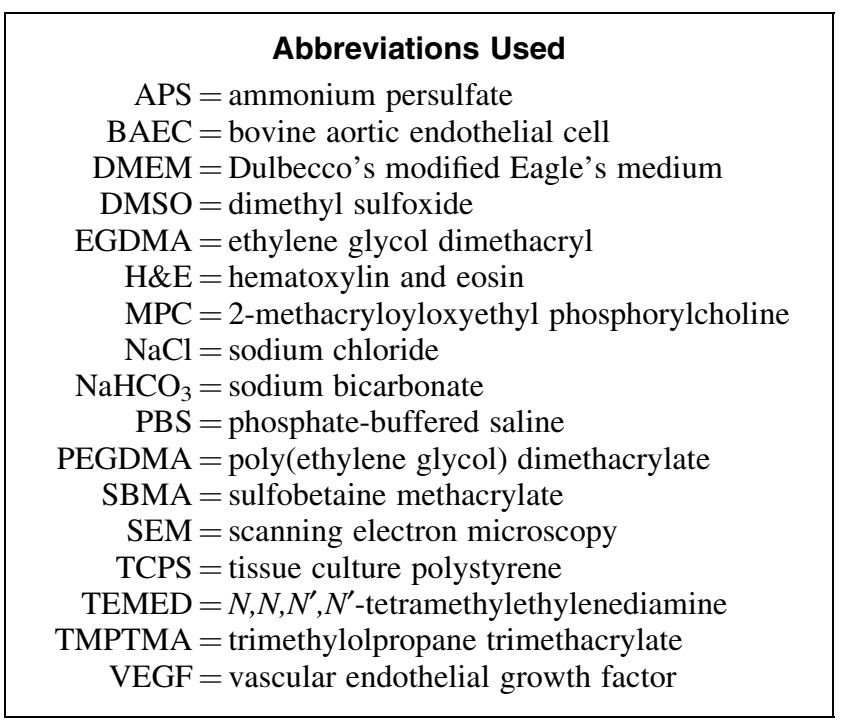

